\author{
小泉 岳司・吉田 明夫
}

\title{
An Investigation on the Effect of Underground Water on the Borehole Volumetric Strainmeter at Yugawara
}

\author{
by \\ Takeshi Koizumi and Akio Yoshida \\ Meteorological Research Institute, Tsukuba, Ibaraki, 305 Japan
}

(Received Decenber 2, 1988 ; Revised January 12, 1989)

\begin{abstract}
The effect of underground water on the borehole volumetric strainmeter is investigated by conducting continuous measurement of the underground water level in the borehole at Yugawara, Kanagawa Pref., central Japan.

The dilatational change soon appears after the rising of the underground water level, but about two days later, the strainmeter begins to show the compressional sense. The former feature may be explained by the effect of underground water that decreases stress in the rock surrounding the strainmeter, which brings about the expansion of volume strain. On the other hand, the latter is explained by the increase of load due to the rising of the underground water level to the rock underneath the water table.

Characteristics of strainmeter response to the change of the underground water level exhibit seasonal variation, which may indicate the change of transfer function due to difference of the underground condition.
\end{abstract}

\section{1.はじめに}

地壳変動観測においては, 気圧・降水等の影響 の評価が重要な問題であり，この覮乱を除去する ため数多くの研究がなされて来ている（例えば田 中, 1979)。さらに, 影響の伝達関数の時間変化は 周辺媒質の状態の変化を表す指標として注目すべ きパラメータである。気象庁が東海・南関東に展 開している体積歪計は気圧, 降水量, 及びそれに 伴う地下水位変動によるとみられる擾乱をうけて おり, 気圧変化によるものについては線型の補正 によってほぼその影響が除去できることが確かめ られている(檜皮ほか，1983）。我々は，この気圧 補正後の歪変化の中から, さらに地下水位変動の 影響を見積り，その除去を行うことでより信頼性 の高い変化を検出するための手法の開発を目指し て, 1985年 4 月以降, 気象庁湯河原体積歪観測点
の観測孔内で地下水位の連続観測を開始した。こ れによって，降水を入力とする場合より容易でか つ精度の高い解析が可能となった。Fig. 1 に観測 点の位置を示す。以下では1985年〜1987年の約 3 年間のデータについて解析を行つた結果について 検討する。

\section{2. 観測孔の環境と観測方法}

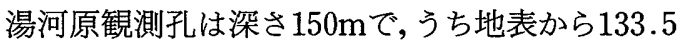
$\mathrm{m}$ まではケーシングが挿入されているが, その下は 裸孔となっている。また，ケーシングとその外側 の孔壁の間はフルホールセメンティング等の処理

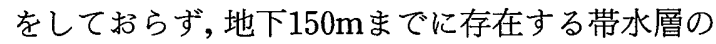
地下水は孔底の裸孔部分を通って孔内に自由に出 入りすることが出来る。Fig. 2 に水位計の設置状 況及び地質柱状図を示す。使用している水位計は 


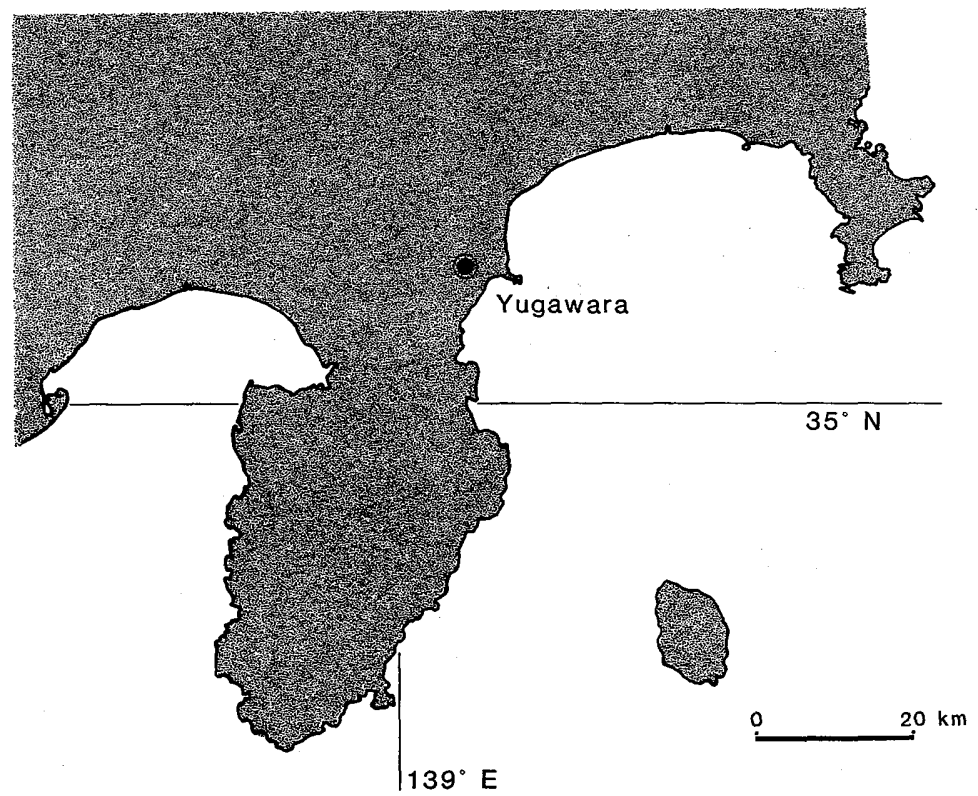

Fig. 1 Location of the Yugawara observation site.
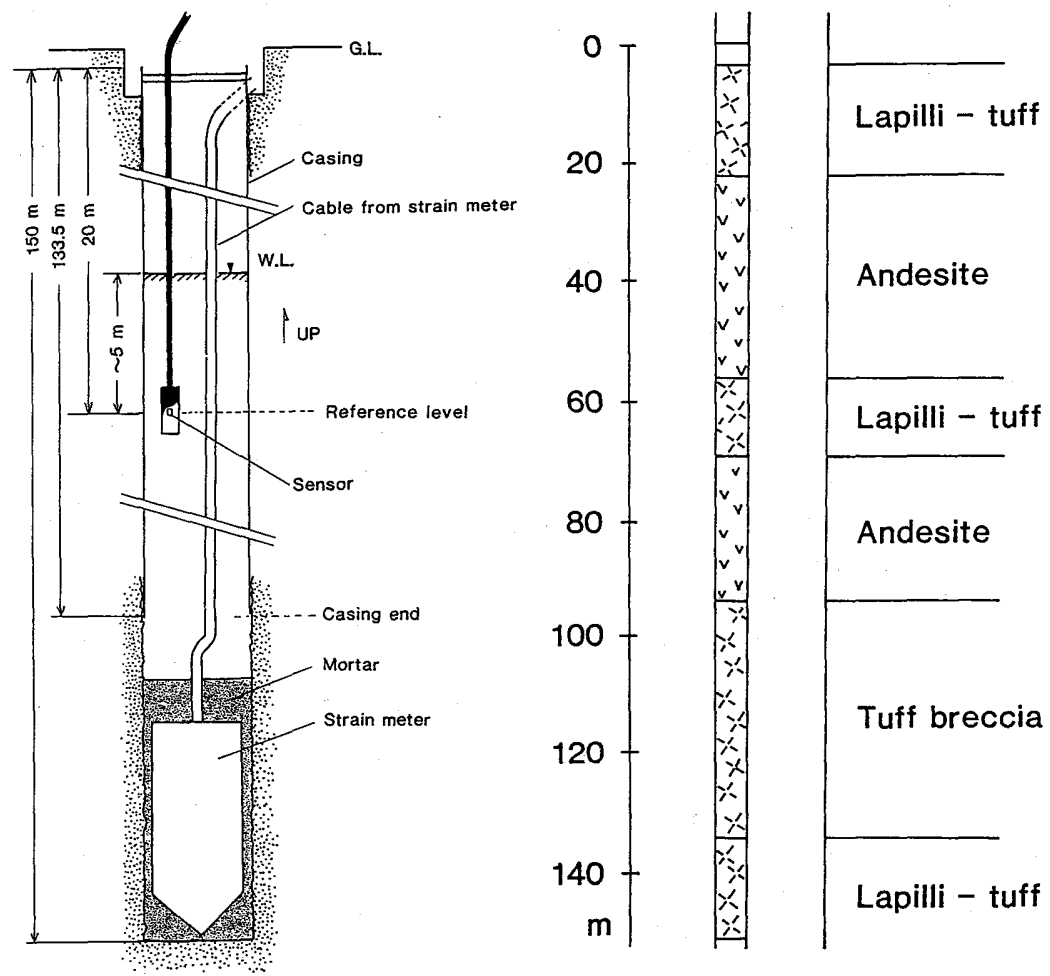

Fig. 2 Borehole conditions and geological columnar map at Yugawara. The borehole is unprotected below 133.5 meters deep, which allows free passage of underground water into the hole. 
圧力式水位計で, 春先の最低水位から約 $5 \mathrm{~m}$ 下に設 置してある。この水位計は大気解放パイプを持ち, 孔内の水面にかかる気圧の影響は除去されるよう になっている。この孔内に人為的に注水してその 影響を調べる実験を行ったが, 約 $4 \mathrm{~m}$ の水位変化に 対して歪計の出力は 6 ナノ strain の変化を示すに とどまった。後述するように, 実際の降水に伴っ て地下水位が数 $\mathrm{m}$ 上昇した場合, 歪計の出力は数 マイクロ strainの変化に示すことから, 歪計に対

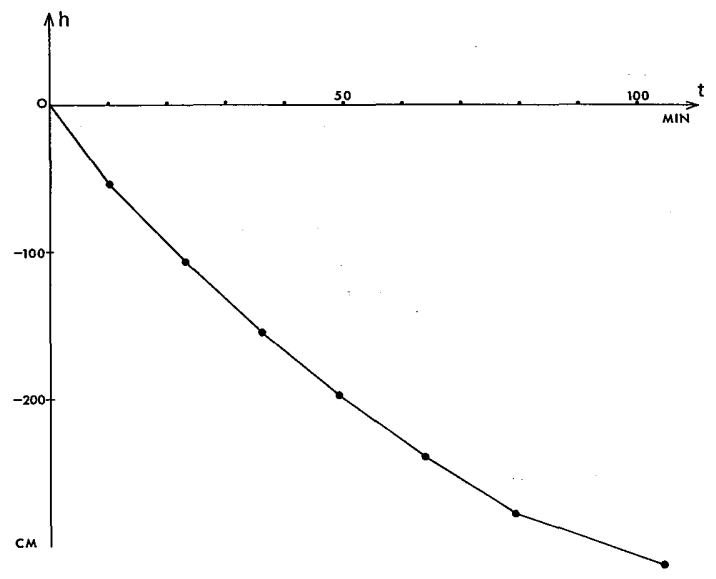

Fig. 3 Lowering of the water level in the borehole at Yugawara, after water is experimentally poured into it. The relaxation time constant is about 100 minutes.
して, 孔内に存在する「水柱」の荷重は無視でき る事がわかる。Fig. 3 はこの注水実験時の水位の 回復状況を示すもので, 得られた緩和時間は約 100 分であった。従って，この観測孔における水位変 化は，ほほ 1 時間程度の時間分解能を有するもの と判断される。

\section{3. 観 測 結 果}

Fig. 4 に1985年 4 月から1987年12月までの観測 結果を示す。図中，上から気圧，歪，水位，及び 降水量で, 降水量以外はすべて 1 時間值である。 この期間, 湯河原に気圧計が整備されていなかっ たため, 気圧データとしては千葉県の富津のデー 夕を，また，降水量は湯河原から南へ約 $13 \mathrm{~km}$ の ころにある網代測候所の日降水量を用いた。歪に ついては，現在気象庁がルーチン的に用いている 気圧係数を使って補正を行った。水位についても 気圧変化の影響を受けているため，1985年 9 月 〜 1986年 2 月の降水量の影響が少ない期間につい て，気象庁が歪の気圧係数を求めたのとほほ同じ 手法で水位の気圧係数を求め, それを用いて気圧 補正を施した。但し水位の場合，降水の影響がき わめて大きいため，一次相関をとる期間の幅を 2 日とし，相関係数0.95以上のものを採用した。こ の水位の気圧係数は，わずかながらその時の水位 によって変化し，杉山ほか（1981）とは逆に，そ の絶対值が水位高と正の相関を持っていることが 判明したが，サンプル数が十分でないため，解析

1985. 4.01.0000-1985.12.31.2300
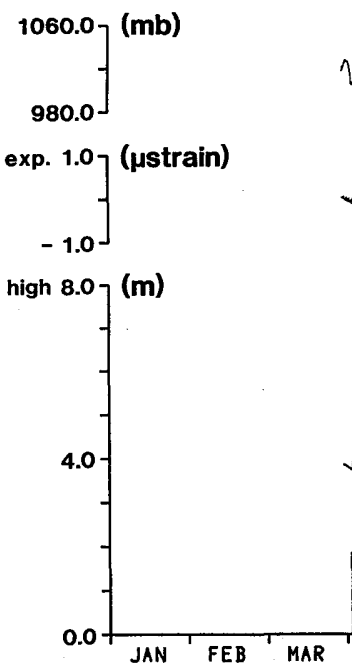

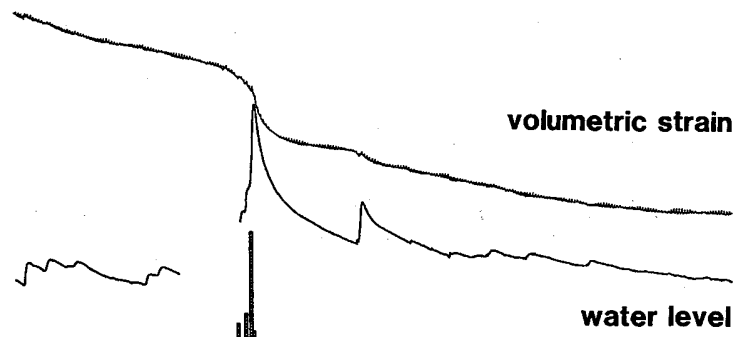

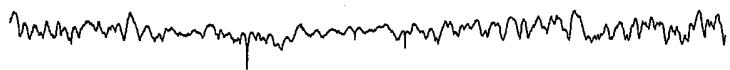

atmospheric pressure

water level

PREC. (30 MM)<smiles>C=[IH]</smiles>

Fig. 4 Secular changes of atmospheric pressure at Futtsu ( $\left(\mathrm{N} 35^{\circ} 13^{\prime}\right.$, E135 $\left.54^{\prime}\right)$, volumetric strain at Yugawara $\left(\mathrm{N} 35^{\circ} 10^{\prime}, \mathrm{E} 139^{\circ} 06^{\prime}\right)$, underground water level at Yugawara and the amount of precipitation at Ajiro (N35 $\left.03^{\prime}, \mathrm{E} 139^{\circ} 06^{\prime}\right)$. 
1986. 1.01.0000-1986.12.31.2300

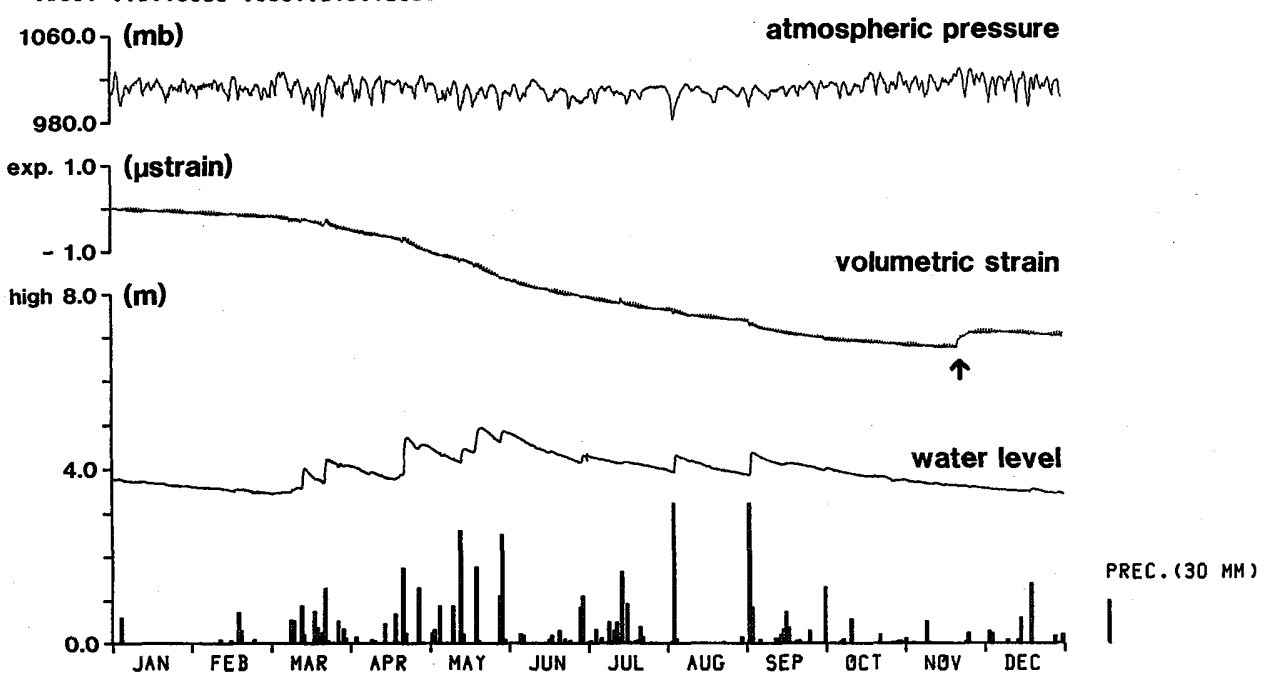

1987. $1.01 .0000-1987.12 .31 .2300$
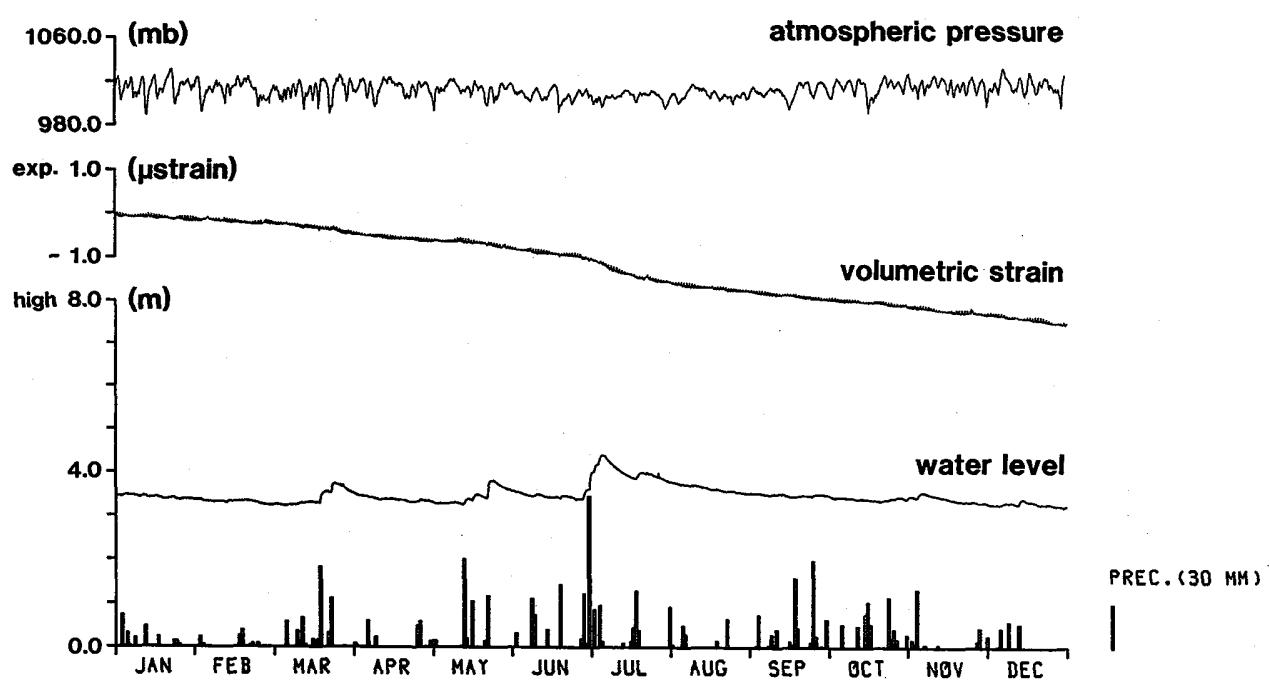

Fig. 4 Continued. 
1985.4.1. $-1985.5 .31 . \quad \mathrm{Lag}=10$ hour

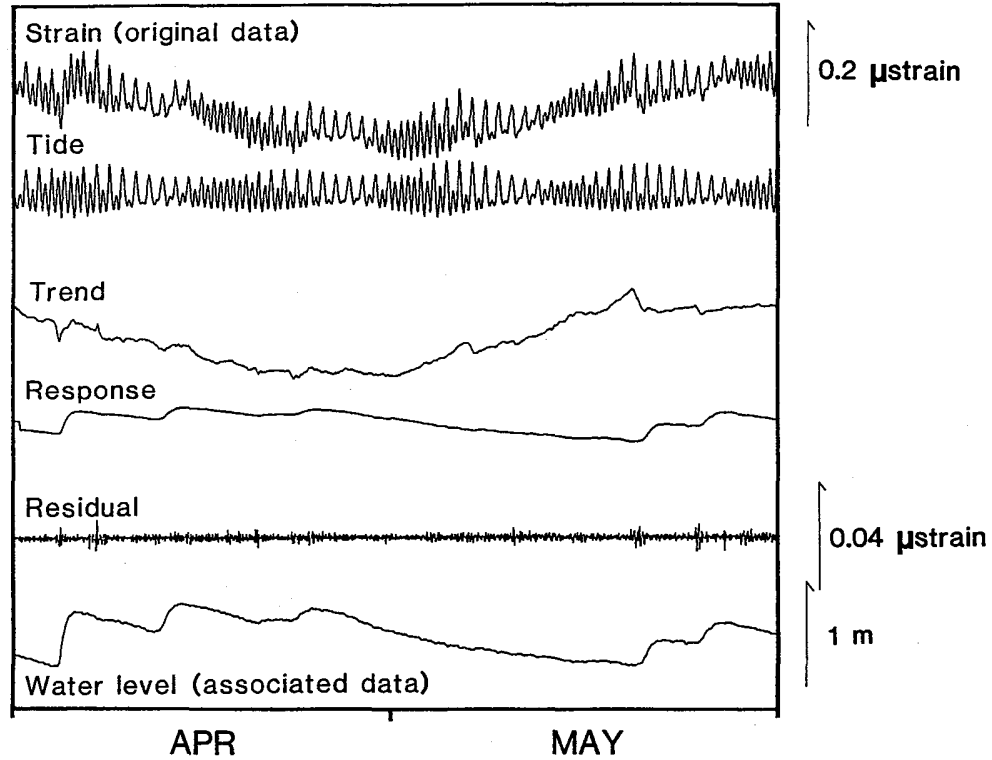

Fig. 5 Hourly value of borehole strainmeter and its analyzed results using Baytap-G (Ishiguro et al, 1984). From the top, the original strain, the tidal component, the trend, the response (to change in the underground water level), the residual and the change of underground water level are shown. It is apparent that the base rock around the strainmeter shows the expansive respons to the rise of the underground water level in a short period (about 10 hours).

1985. 8. 1 - 1986. 7.31. Lag: 10 days

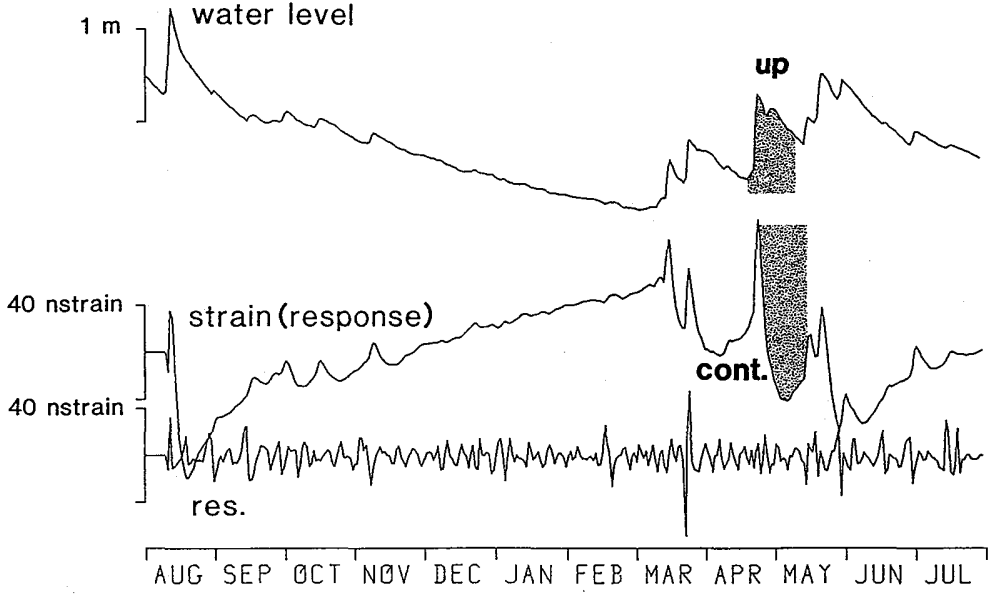

Fig. 6 Long-period (about 10 days) response of strain to change in the underground water level, in which the daily mean data are used. Soon after the rising of the underground water level, the base rock shows the same response (expantion) as in the case of short period. But a few days later, it begins to show negative response (contraction). 


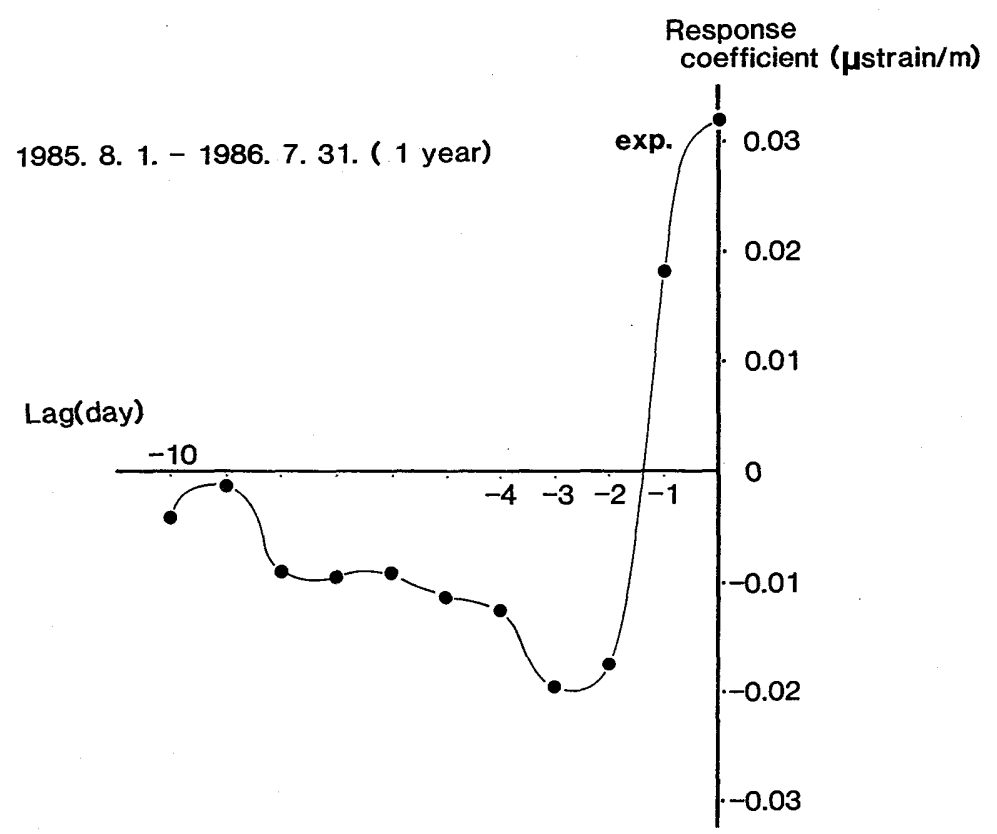

Fig. 7 Response coefficients of strain to change in the underground water level. The abscissa represents time lag (unit: day). In this figure, reversal of the response cofficients (expansion $\rightarrow$ contraction) is observed, which explains the reversal of the response in Fig. 6 .

には得られた係数の全てを単純に算術平均をとっ て気圧係数とした。図中, 歪については上が膨張, 水位については上が up で,水位はセンサーの位置 を基準としている。これをみると，水位の上昇に よって歪は縮みの変化を示し，湯河原観測点にお いては, 地下水は基本的に荷重としての働きをし ている事がわかる。特に1985年 6 月〜 7 月にかけ ての変化量は，1986年11月21日の伊豆大島の割れ 目噴火に伴うステップ状の変化 (図中个印) の約 3.5倍にも達しており,地下水位の変化によって生 じる歪変化は, 広域の応力場の変化に伴う歪変化 とほぼ同じオーダーか，場合によってはそれをし のぐ場合がある事を示している。従って，地震の 前兆等の監視には地下水位のモニターがきわめて 重要である事がわかる。以下では，水位変化に対 する歪の応答について更に詳しくみてみる。

\section{4. 地下水位変化に対する歪の応答}

Fig. 4 からは，数か月程度の時間スケールでの 「水位上昇 $\rightarrow$ 歪縮み」という傾向が直ちに見て取 れるが,より短い周期での変化を調べるため, 1985 年 4 月 1 日から 5 月 31 日までの 2 か月間のデータ
（1 時間値）を用い，石黒ら (1984)によるBaytap -Gを用いてその応答をみてみた。Fig. 5 にその結 果を示す。解析に用いたラグは 10 時間で，これは 10時間前までの水位変化が歪変化に影響を与えて いると仮定してその伝達関数を推定し，応答を計 算している事に相当する。図は, 上から歪の生デー 夕, 推定された潮汐成分, トレンド, 水位変化に 対する応答, 残差, そして入力としての水位変化 をそれぞれ示している。歪に対するスケールは残 差以外はすべて同じである。これをみると，水位 上昇に対する歪の応答は膨張を示し，周期10時間 程度の時間带では，さきほど示した「水位上昇 $\rightarrow$ 縮み」とは明らかに異なるふるまいを示すことが わかる。そこで, 数か月程度の周期と10時間程度 の周期をつなぐ部分をみるために，日平均值を用 い，ラグを10日として同様に歪の応答を求めた結 果をFig. 6 に示す。これをみると，水位の上昇に 伴って歪は直後に一時膨張し, その後大きく縮み の変化を示すことがわかる。このことをもう少し わかりやすく見るため, 歪のレスポンスウエイト の係数(図中ではレスポンス係数と略す)をプロッ トしたものがFig.7である。これをみると，当日 $(\mathrm{Lag}=0)$ と 1 日前 $(\mathrm{Lag}=-1)$ の係数は正で, 


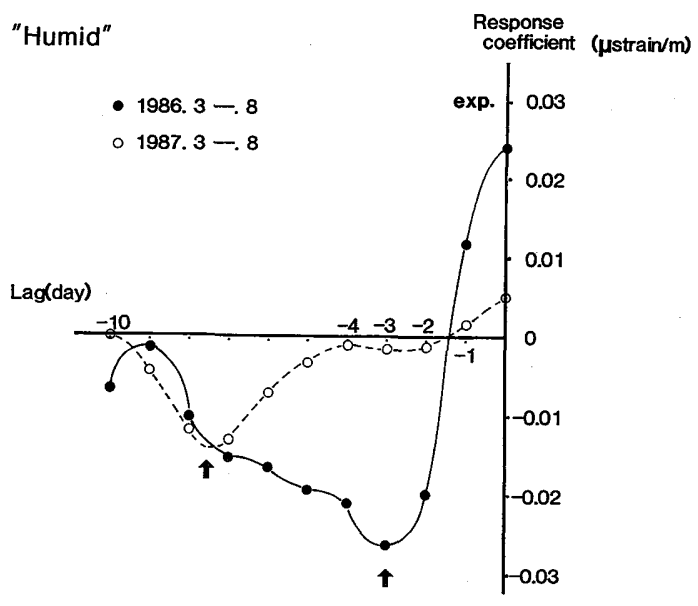

Fig. 8 (a) Response coefficients of strain in the rainy season.

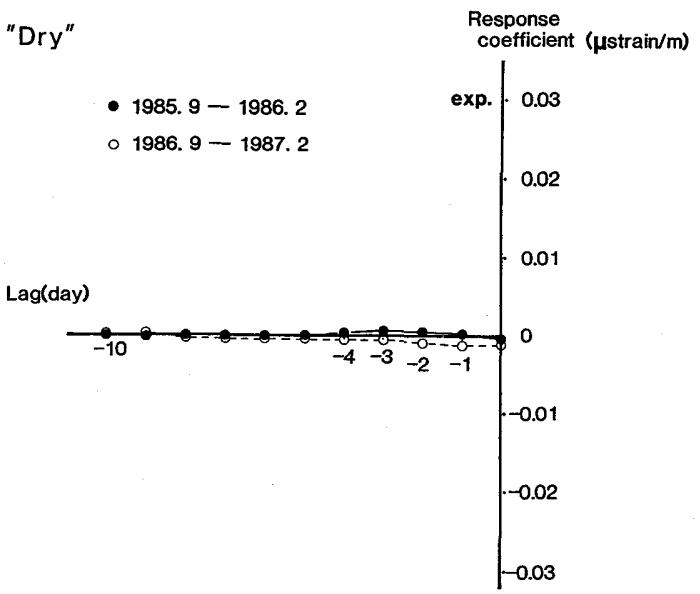

Fig. 8 (b) Response coefficients of strain in the dry season.

これは水位の上昇に対し歪が膨張の応答を示すこ とを意味し，Fig. 5 に見られた変化と一致する。

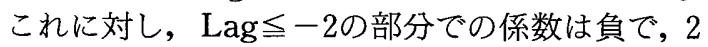
日以前の水位の上昇に対し, 歪は縮みの応答を示 す。言いかえれば，水位の上昇は 2 日遅れて歪に 荷重としての作用を及ぼしはじめる事を示してい る。体積歪計の観測点によっては, 水位の上昇に よって歪に膨張の変化の現れる観測点 (静岡) と, 逆に縮みの変化の現れる観測点（網代）とがあり, これは帯水層の位置のちがいによるのではないか とされている(吉田ほか, 1984)。即ち, 前者の場 合，歪計のセンサーが，観測される地下水を供給 する帯水層の中か, そのごく近傍にあり，地下水 位の上昇による間吵水圧の上昇によって岩盤に働
く応力場が小さくなるため, 膨張の応答を示すの に対し, 後者の場合, センサーより上部に帯水層 があるために，その帯水層の地下水が歪計に対し 荷重として作用する事により,「地下水位の上昇 $\rightarrow$ 縮み」といった応答がみられるという訳である。 このことを今回の場合にあてはめて考えると次の ようになる。即ち, 湯河原観測孔の場合, 歪計の センサー付近にごく局所的な広がりをもった帯水 層が，またセンサーより浅い部分にはより広域的 な広がりをもった帯水層があわせて存在する。降 水直後, 歪計にはセンサ一付近の局所的な帯水層 の間隙水圧の上昇による膨張の応答が卓越するが, その後, より広い範囲に降った雨の影響による広 域の地下水が荷重として作用するようになる。降 水直後にも広域の帯水層の水頭上昇による荷重効 果は存在するが，これを打消すだけの膨張の効果 が存在する, と考えれば矛盾はない。この一連の メカニズムは, 小沢 (1984) や, 二瓶・佐藤 (1988) による静岡の場合と異なり, 帯水層の位置, 大き さによっては様々な場合が存在することを示して いる。いずれにしても, 湯河原観測点は歪計に影 響を与える帯水層を捉えているため, その水位変 化を連続してモニターする事で, 歪計のデータに 対する, いわば水位補正が可能となる訳で, 今後 同じょうなタイプの観測を行う場合には地下水位 観測がきわめて重要であると思われる。

\section{5. 応答の季節特性}

前節では一年間のデー夕を用いて地下水位変化 に対する歪の応答をみたが，その応答特性は一年 を通して，あるいはそれ以上の長い期間にわたり 一定しているのであろうか。このことをみるため に,一年を 3 月から 8 月までの雨の多い湿潤期と, 9 月から 2 月までの乾燥期とに分けてレスポンス ウエイトの係数を求めてみたのがFig. 8 (a), (b) である。これをみると, 両者できわめて明瞭に応 答が異なり，また，高々 2 年分のデータではある が，同じ湿潤期でも年によってその応答の様子が かなり異なっていることがわかる。これは島津ほ か（1985）の指摘するように，降水に対する帯水 層の水位の上昇, 及びその歪計への作用が線型で ない事を示す。と同時に, 二瓶・檜皮（1983）に あるように，その時々によって，例えば地盤の湿 り具合によって伝達関数の形そのものが変化する 事を示している。即ち, 1986年の湿潤期に比べ 1987 年のそれのレスポンスウェイトの係数が小さく, さらに図中に矢印で示した最も縮む時間遅れが異 なるのは1987年の平均水位が1986年に比べて低く, 
地盤が相対的に乾いていた事によると考えられる。 従って，もしリアルタイムに水位補正を行おうと する場合には，水位変化量だけでなく，その時の 水位そのものも入力パラメー夕に加えなくてはな らない事を示し, 水位補正の実用化には, この点 も考慮に入れた解析が必要である。

\section{6. まとめ}

湯河原体積歪観測井での水位の同時連続観測に より,歪計に及ぼす地下水位変化の影響を調べた。 その結果, 湯河原では, 降水後の地下水位の上昇 に伴い, 歪はまず膨張し，その後，約 2 日の時間 遅れで縮みのセンスを示すようになる事がわかっ た。これは，歪計センサー付近のごく局所的な帯 水層と, より広い範囲の, 歪計に対して荷重とし ての作用をする帯水層といった複数の帯水層の存 在によるものと考えられる。また，その応答特性 は季節により大きく異なり，これは，地下の状態 の違いにより, 降水 $\rightarrow$ 水位 $\rightarrow$ 歪と影響が伝わって いく伝達関数の形そのものが変化する事を示して いるものと思われる。歪のリアルタイムの水位補 正には，この点も含めた解析が必要である。

\section{謝辞}

水位観測の継続にあたり気象庁地震予知情報課 解析係及び予知技術係の多くの方々のご援助, 御 指導をいただき，厚く御礼申し上げます。特に， 二瓶信一氏には，水位計の設置当初から並々なら
御助力をいただきました。また,気象研究所吉 川澄夫氏には終始有益な御指導を頂き, ここに記 して嬮く御礼申し上げます。

\section{参考文献}

檜皮久義, 佐藤 馨, 二瓶信一, 福留篤男, 竹内 新, 古屋逸夫, 1983：埋込式体積歪計の気圧補正. 験 震時報, 47, 91-111.

石黒真木夫，佐藤忠弘，田村良明，大江昌嗣，1984： 地球潮汐デー夕解析——プグラムBAYTAPの紹 介——. 統計数理研究所彙報, 32, 71-85.

二瓶信一, 檜皮久義, 1983 ：三ヶ日における埋込式体 積歪計に対する降雨の影響. 験震時報, 48, 18-22.

二瓶信一，佐藤 馨， $1988 ：$ 埋込式体積歪計による観 測 (2) 一一歪観測における地下水調查一一験震 時報, 51，93-106.

小沢泉夫, 1984 ：旧逢坂山トンネルにおる打る体積ひず みの長期観測. 測地学会誌，30，122-130。

島津好男, 福留篤男, 吉田明夫, 1985 : 御前崎の体積 歪変化について. 気象研究所研究報告, 36, 209-217.

杉山雄一, 佃 栄吉, 加等 完, 池田喜代治, 1981： 東海地域の地下水観測デー夕の解析一一地下水位 変動の解析（その 1 ) 一一. 地質調查所月報, 32 , 133-150.

田中寅夫，1979：傾斜計・伸縮計記録に現れる降雨の 影響とそのシミュレーション. 測地学会誌, 25 , 91-100.

吉田明夫，二瓶信一，太田金房，薄田真司，1984：静 岡と網代における体積歪観測孔内の水位変化と歪 変化. 気象研究所研究報告, 35, 199-207.

\title{
湯河原体積歪計に対する地下水の影響
}

\author{
小泉岳司・吉田明夫
}

湯河原体積歪観測井での水位の同時連続観測により，歪計に及ぼす地下水位変動の影響を調べた。その結果， 湯河原では, 降水後の地下水位の上昇に伴い, 歪はまず膨張し，その後，約 2 日の時間遅れで縮みのセンス を示すようになる事がわかった。これは, 歪計センサー付近のごく局所的な帯水層の間隙水位の上昇による 岩盤の膨張と, より広い範囲の帯水層の歪計に対する荷重が合成された効果と考えられる。また，その応答 特性は季節により大きく異なり, これは, 地下の状態の違いにより, 降水 $\rightarrow$ 水位 $\rightarrow$ 歪と影響が伝わっていく 仕方を表す伝達関数の形そのものが変化する事を示しているものと思われる。 